\title{
Determinants of Vertical Integration in Poultry Production in Ghana: Application of Count Data Models
}

\section{Faizal Adams ( $\sim$ fazztop@gmail.com )}

Kwame Nkrumah University of Science and Technology College of Agriculture and Natural Resources https://orcid.org/0000-0002-2225-5501

\section{Amos Mensah}

Kwame Nkrumah University of Science and Technology Faculty of Agriculture: Kwame Nkrumah University of Science and Technology College of Agriculture and Natural Resources

\section{Seth Etuah}

Kwame Nkrumah University of Science and Technology Faculty of Agriculture: Kwame Nkrumah University of Science and Technology College of Agriculture and Natural Resources

\section{Robert Aidoo}

Kwame Nkrumah University of Science and Technology Faculty of Agriculture: Kwame Nkrumah University of Science and Technology College of Agriculture and Natural Resources

\section{James Osei Mensah}

Kwame Nkrumah University of Science and Technology Faculty of Agriculture: Kwame Nkrumah University of Science and Technology College of Agriculture and Natural Resources

\section{Research}

Keywords: Poultry production, transaction cost, food security, poverty reduction,

Posted Date: May 7th, 2021

DOI: https://doi.org/10.21203/rs.3.rs-492172/v1

License: (1) (1) This work is licensed under a Creative Commons Attribution 4.0 International License. Read Full License 


\title{
Determinants of Vertical Integration in Poultry Production in Ghana: Application of Count Data Models
}

\section{By}

\author{
Faizal Adams*, Amos Mensah, Seth Etuah, Robert Aidoo and James Osei Mensah
}

Department of Agricultural Economics, Agribusiness and Extension, College of Agriculture and Natural Resources, Kwame Nkrumah University of Science and Technology Kumasi, Ghana. Emails; Amos Mensah (mensahamos@yahoo.co.uk), Seth Etuah (etuah.seth@yahoo.com) and Robert Aidoo (badubob@yahoo.co.uk), James Osei Mensah (mojemmy@gmail.com).

*Corresponding author: Faizal Adams; Telephone: 233-268818687; Email: fazztop@ gmail.com 


\title{
Determinants of Vertical Integration in Poultry Production in Ghana: Application of Count Data Models
}

\begin{abstract}
Poultry production has significant potential to reduce protein deficiency, food insecurity and poverty in Ghana. However, limited vertical integration and high cost of production in the sector have stifled growth and exposed poultry farms in the country to many risks, leading to poor business performance. This study uses cross-sectional data from 102 commercial poultry farms to assess the determinants of extent of vertical integration in the Ghanaian poultry industry by employing zero-inflated Poisson (ZIP) and Zero-inflated Binomial (ZINB) models. The results show that one in every four poultry farms in the country are vertically integrated, either partially or fully. The ZINB model, which best fits the data, reveals that the extent of vertical integration in the poultry business is significantly influenced by a set of personal (education, occupation, and farming experience) and farm level (land tenure, flock size, production cost, and farm revenue) characteristics as well as institutional factors (credit access, extension access and membership of association). The paper discusses the implications of these findings and provides appropriate recommendations for strengthening the poultry industry in Ghana.
\end{abstract}

Key words: Poultry production, transaction cost, food security, poverty reduction, 


\section{Determinants of Vertical Integration in Poultry Production in Ghana: Application of Count Data Models}

\section{INTRODUCTION}

Poultry, widely termed as the "cow" of the poor, has the potential to improve nutritional security and ensure poverty reduction across sub-Saharan Africa (SSA) (Food and Agriculture Organisation, 2010). In Ghana, poultry production makes a significant contribution to the economic growth of the country (Adei and Asante, 2012; Atuahene et al., 2010). The sector accounts for about $34 \%$ of domestic meat production and employs nearly 2.5 million people, of which the majority are women who subsist on poultry and other related products for livelihoods (Guèye, 2000; Ministry of Food and Agriculture [MoFA], 2020). Despite its influential contribution to the growth of the economy, the Ghanaian poultry industry, over the past decades, has declined due to intense competition from imported poultry products and high cost of production (Kusi et al., 2015; Anang et al., 2013; Atuahene et al., 2010). For instance, official data shows that domestic broiler meat supply has declined from $60 \%$ to $20 \%$ culminating in an increase in imports from 13,900MT to over 155,000MT in 2018 (Figure 1) (FAOSTAT, 2019).

To help create a more competitive and efficient poultry industry, the United States Development Agency (USDA) implemented the Ghana Poultry Project (GPP) from 2015 to 2020 (USDA, 2017). This was further strengthened by the introduction of the "Rearing for Food and Jobs" program by the Government of Ghana to produce 40,000MT of broiler meat by the end of 2020 (MoFA, 2019). In these initiatives, much emphasis were placed on strategies such as the provision of subsidized inputs, producer's capacity building, and strengthening of buyer-supply linkage to minimize the cost of production and improve the overall competitiveness of the Ghanaian poultry industry (Anang, 2013; Global Agricultural Information Network (GAIN) report, 2017). 


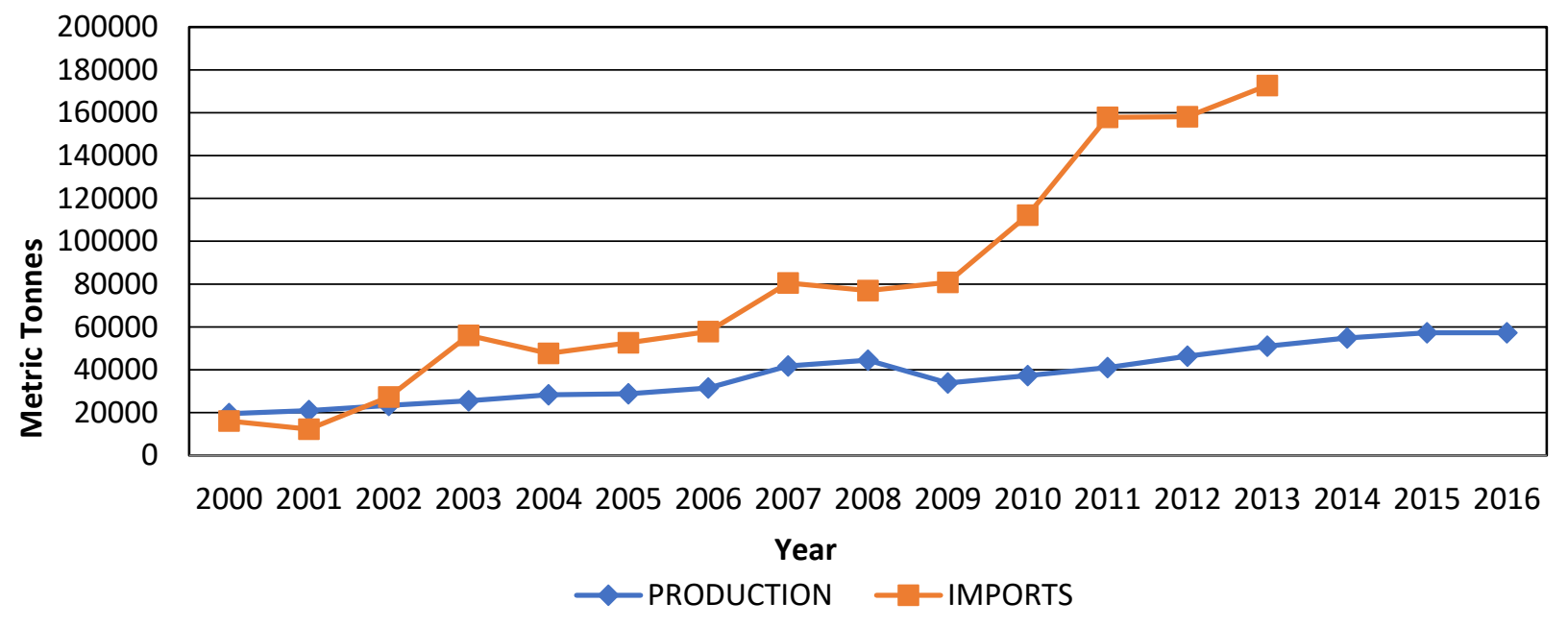

Figure 1: Production and Importation of Poultry in Ghana, 2000-2016 Data source: FAOSTAT Database, Various Years

However, an important management strategy that has a significant influence on the overall performance and competitiveness of the poultry industry but has received little attention in these initiatives is vertical integration. Reasons such as limited empirical data on the implications of vertical integration in poultry farming are adduced to this apparent lack of consideration in poultry development programs of Ghana (Atuahene, 2010). This study, therefore, presents an empirical analysis of the extent and determinants of vertical integration of poultry production in Ghana. A thorough understanding of the implication of vertical integration in poultry farming is a prerequisite to guide policy intervention that will improve the efficiency and competitiveness of the poultry sub-sector of the country.

Empirical studies on vertical integration as a key catalytic operation to expand and improve the competitiveness of firms have been well-documented (Baum, 1951; Coarse, 1937; Buzzel, 1983; Maddigan, 1981; Grega, 2003; Martinez, 2012). Isaksen et al. (2002) suggests that vertical integration of firms helps to reduce production costs while improving efficiencies. In a multi-study of agricultural products, Maritinez (2012) observes that not only does vertical integration enable 
firms to eliminate risk and uncertainties, but to overcome market failures and expand market power for competitive advantage. Thus, the general motive for firms to integrate vertically is to reduce the overall cost of production, which in turn, improves firms' performance and consumer welfare (Carlton and Perloff, 2005). Despite this, there are only few studies (e.g. Bamiro et al., 2006; Bamiro and Shittu, 2009; Bamiro et al., 2014) across sub-Saharan Africa that consider vertical integration of poultry farms as a conduit to increase competitiveness and efficiency of the sector. Moreover, the findings of these limited studies have generally been mixed and inconclusive (Bamiro et al., 2006; Bamiro and Shittu, 2009; Bamiro et al., 2014). This is because the overreliance on the use of value-added ratio as a proxy to measure the extent of vertical integration of poultry farms is fairly limited (Barrera-Ray, 1995). According to Hamdaoui and Boyuad (2019), the two economic variables of sales and purchases, which are key indicators of value-added ratio in the determination of vertical integration, may be influenced by other factors (such as production techniques and staff competencies) besides vertical integration. In this study, therefore, we compute a vertical integration index based on available data to measure the extent of vertical integration in poultry production. We also examine the key determinants of extent of vertical integration by paying special attention to important farmer, farm level, and institutional factors. The rest of the study is organized as follows. First, theoretical concept of vertical integration and its measurement are reviewed in Section II. The research method is presented in Section III before

results and discussions in Section IV. Conclusions and recommendations of the study are also outlined in Section V.

\section{VERTICAL INTEGRATION AND ITS MEASUREMENT}

The concept of vertical integration has been popular in economics literature since the era of Adams Smith, and the division of labour theory propounded by Young (1928), and Stigler (1951). Yet to 
date, there is no universally accepted definition of the concept (see, for instance, Coase, 1937; Buzzell 1983; Rehber, 1998; Luciana, 2008; Basant and Mishra, 2017). Despite the diversity in the definitions, a common understanding as adopted in this study suggests that firms are vertically integrated when they partially or wholly internalised their operations without the involvement of external agents. Thus, in a vertically integrated firm, two or more production stages occur under one management where all upstream production activities serve as inputs for downstream activities and vice versa (Hamdaoui and Bouayad, 2019). As a result, the product developed is not transmitted via the market and, hence, does not reflect market prices (Hamdaoui and Bouayad, 2019). In summary, Barrera-Ray (1995) contends that the stages of production in a vertically integrated firm should be contiguous without intermediaries and no market exchanges. There are two basic types of vertical integration: backward and forward vertical integration (Grega, 2003; Barrera-Ray, 1995; Bamiro and Shittu, 2009). A firm engages in backward integration when it produces its input instead of relying on external stakeholders. In the case of forward integration, firms take ownership of upstream activities that include distribution, processing, or supply of the firm's final product to consumers. Therefore, to accurately measure the full implication of vertical integration on a firm, both backward and forward integrations have to be sufficiently captured.

The measurement of vertical integration across industries is complicated and poses several practical and theoretical hurdles, which limit the ability of researchers to examine the extent of vertical integration on firms' performances (Hamdaoui and Bouayad, 2019). Nonetheless, two distinct measures of vertical integration can be identified in the literature. These include measures determined from financial statements and the use of multidimensional constructs such as computation of indices based on available data (Kaiser and Obermaier, 2020). 
In terms of financial measures, the Value Added to Sales (VAS), proposed by Adelman (1955), is the most widely used approach to proxy a firm's degree of vertical integration. The VAS is mathematically friendly and has a strong theoretical foundation because it is defined by two economic variables as $V A S=($ sales - purchases $) /$ sales (Buzzel, 1983). Despite its simplicity, the VAS has many drawbacks, which makes it near impossible to be applied in firms that operate in the informal sector such as poultry production in developing economies. First, the approach measures monetary values, which can be influenced by other factors such as efficiencies of production techniques and employees (Hamdaoui \& Bouayad, 2019), and not on physical activities/transactions that contribute to the degree of vertical integration (Barrera-Ray, 1995). Similarly, the measure is criticised as not being symmetric concerning production stages, as it favours upstream activities (Barrera-Ray, 1995; Isaksen et al. 2002). Lastly, not only is the VAS dependent on financial indicators that are sensitive and confidential, but records on these indicators are poorly kept, especially for informal firms in developing countries (Essel et al., 2019). However, the VAS is the dominant approach used in the few existing studies that consider vertical integration of poultry production across sub-Saharan Africa (See, for instance, Bamiro et al., 2006; Bamiro and Shittu, 2009; Bamiro et al., 2012).

In this study, we adopt a more data-driven approach (vertical integration indices) that permits the use of reliable and readily available data of poultry farms to measure the extent of vertical integration. The indices proposed by Chapman and Ashton (1914), and Gort (1962) based on the number of equipment and employees respectively used in different stages of production within the firm were adopted and modified to calculate the extent of vertical integration of the Ghanaian poultry industry. In this modified approach, the poultry farm's main activity (i.e., production of eggs and meat) is separated from its auxiliary activities and values assigned to each activity in the 
poultry value chain. Empirically, six (6) major auxiliary activities are performed along the value chain. These include ownership of crop farm (mainly maize), feed mill, hatchery, delivery van, processing plant and retail outlet (Begum, 2005). The number of activities engaged in by each poultry farm is expressed as a ratio to the number of major activities in the value chain. Mathematically, the degree of vertical integration adopted in this study is expressed as:

$V_{i}=\sum\left(\frac{n_{i}}{N}\right) \times 100 \%$

where, $V_{i}$ is the extent of vertical integration expressed in percentage, $n$ is the number of activities engaged in by $i t h$ poultry farm and $N$ represents the number of major auxiliary production stages in the poultry value chain.

This approach is similar to the index employed by Hamdaoui and Bouayad (2019) to measure the extent of vertical integration in the Moroccan textile industry. The following criteria as defined by Misund (2016) are used to categorise the poultry farms based on the extent of vertical integration, which was used in the further econometric analysis (see Table 1).

Table 1 Benchmark for the Levels of integration

\begin{tabular}{l|l}
\hline Ratio (Percentage) & Level of vertical integration \\
\hline Less than $20 \%$ & Non-integrated \\
$20 \%$ to $65 \%$ & Partially integrated \\
Greater than $65 \%$ & Fully integrated \\
\hline
\end{tabular}

Source: Adopted from Misund (2016)

\section{RESEARCH METHODS}

\subsection{Study area}

The study was conducted in the Dormaa municipality located in the western part of the Bono region of Ghana (Figure 1). The municipality has a total land area of $1210.28 \mathrm{~km}^{2}$ with a population of 112,111 , representing $4.9 \%$ of the national population. Dormaa has an agrarian economy that employs $68.4 \%$ of its total population. About $73 \%$ of the population is located in rural 
communities. Crop and livestock framings are the major agricultural activities in the area. The Municipality is noted for the production of poultry, which constitutes more than $70 \%$ of the total livestock production in the area. Besides, the old Brong Ahafo region (now comprising Bono East, Bono, and Ahafo) is ranked third in terms of poultry production in Ghana with Dormaa municipality contributing more than $80 \%$ to the regions' poultry population (Anang et al., 2013; Kusi et al., 2015). Though there are two major poultry production lines; broiler and layer, nearly $90 \%$ of the poultry farms in Dormaa and its environs are engaged in layer production (Adei and Asante, 2012).

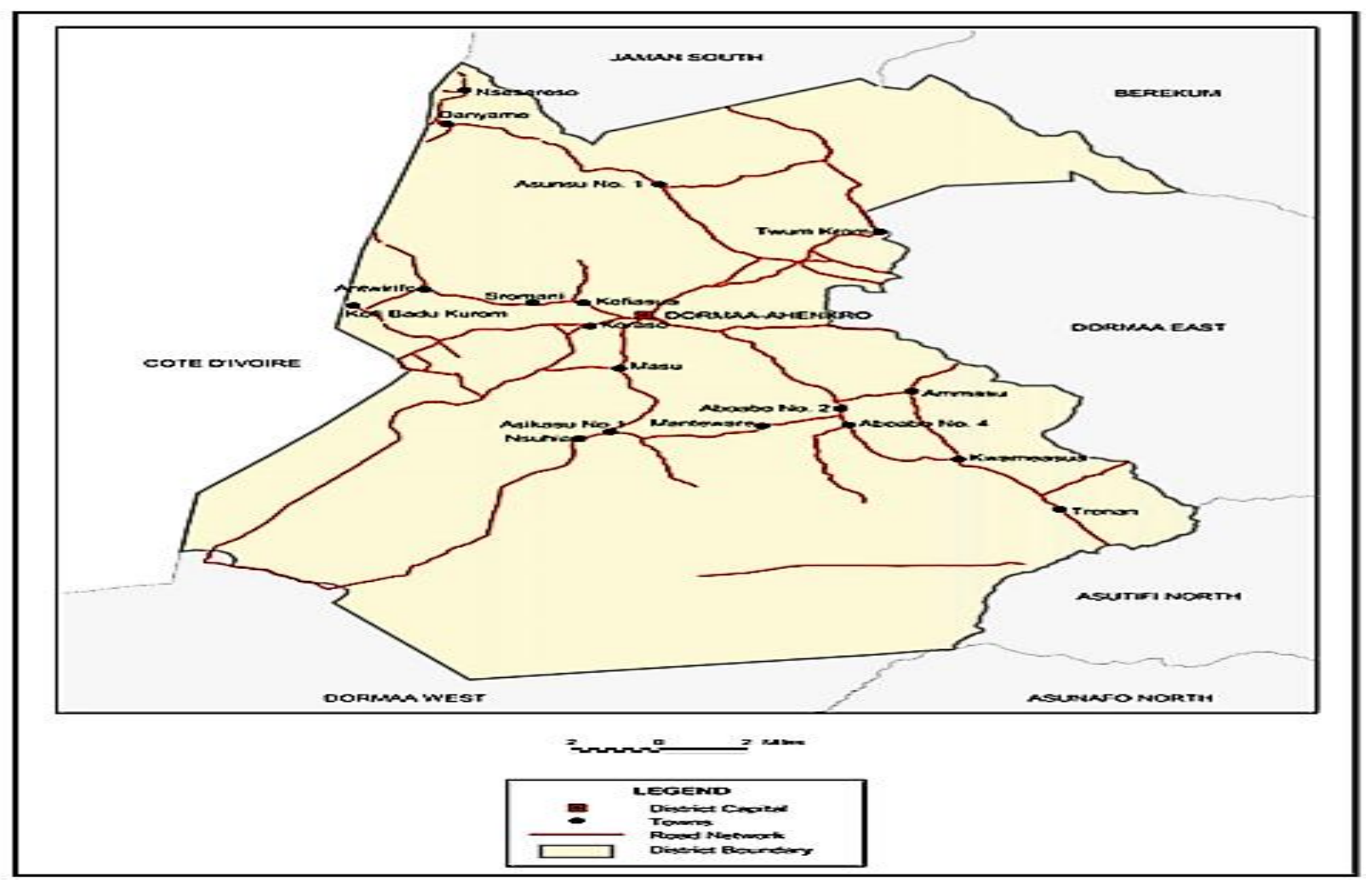

\section{Figure 1 Map of Dormaa Municipality}

(Ghana Statistical Service, [GSS] 2010)

\subsection{Study design and data collection procedure}

The mixed research technique that comprises both quantitative and qualitative designs was used to carry out the study. Combining the two techniques helps to improve the reliability and validity 
of the data collected through data triangulation. Qualitative methods such as focus group discussions and key informant interviews were conducted with leaders of the poultry associations and the Municipal agricultural officers. The focus group discussion comprises seven (7) participants consisting of four (4) male and three (3) female poultry farm owners. In total, 4 focus group discussions were conducted with one each in the 4 selected poultry producing communities in the study area. Key qualitative data collected included farmers' perception of vertical integration, bottlenecks to practicing vertical integration as well as general production and marketing information. On the other hand, a structured questionnaire was developed and used to solicit quantitative information on the poultry farms (i.e., size of farms, production cost, revenue, upstream and downstream poultry activities, among others), producers' demographics, and access to relevant institutions such as the veterinary services.

The study employs cross-sectional data collected between February and March 2020. The data collected was based on the 2019 production year. Prior to the data collection, the survey questionnaire was pre-tested in one community in the study area to assess the appropriateness of the statements towards meeting the objectives of the study. Seven (7) poultry farmers were randomly selected and used in the pre-testing.

The study conducted a full census to include all the 137 registered commercial poultry farms in the Dormaa municipality. The list of all the farms was obtained from the leadership of the poultry farmers' associations in the municipality. The veracity of the list was authenticated at the Municipal Department of Agriculture. Information on other poultry farms not registered were also solicited from the Department and were contacted for data collection. In total, managers and owners of 102 poultry farms were available for data collection within the survey period. The 
communities included in the survey are Wamfie (15)1 , Dormaa Ahenkro (35), Kyeremasu (12), Asuochia (10), Nkrankwanta (30), and Nsesreso (10).

\subsection{Analytical approach}

Descriptive tools including frequency tables, pie chart and measures of central tendencies and dispersions were used to summarise key farm level and personal characteristics. The zero-inflated Poisson (ZIP) and negative binomial (ZINB) regression models were used to examine the precursors of extent of vertical integration in the poultry business. The zero-inflated models were chosen for the study because less than half of all poultry farms in Dormaa were found to be vertically integrated; leading to the situation/problem of excess zeros in terms of extent of integration (Atuahene et al., 2010). The ZIP and ZINB models were compared and the model that best fitted the data was selected for further discussion.

\subsubsection{Zero-inflated Poisson and Negative Binomial models}

In socio-economic studies, outcomes of interest are sometimes count data with excessive zeros (Fang, 2013). While these zeros are important and meaningful, most researchers often treat them as missing values or delete them. In other cases, the data is either transformed into a linear model (which violates the normality assumption) or coded as a categorical dummy variable where all zeros are considered as 'absent' and those observed as 'present' (Lewsey and Thomson, 2004; Yusuf et al. 2018). Under such circumstances, the analysis becomes less useful and less informative if the interest is to determine the number of occurrences (Yusuf et al., 2018).

Zero-inflated model can distinguish between the two processes causing the excess zeros (Diallo et al., 2019; Yusuf et al. 2018). A common feature of zero-inflated model is its ability to

\footnotetext{
${ }^{1}$ Numbers in brackets denotes size of farmers selected in each community
} 
simultaneously produce two outcomes in count data models by: i.) examining the effects of covariates on the extra/inflated zeros and, ii) generating Poisson or negative binomial aspect of the model (Diallo et al., 2019; Fang, 2013; Lewsey and Thomson, 2004).

Zero-inflated Poisson and -negative binomial models are specialized types of Poisson regression models that are widely employed in count data analyses with inflated zeros (Fang, 2013; Lambert 1992; Diop et al., 2016; Diallo et al., 2017). Lambert (1992) first developed the zero-inflated Poisson after the standard Poisson regression model failed to produce efficient estimates with excess zeros in count data variables. Similarly, modeling a zero-inflated count data that has overdispersion problems with ZIP also produces coefficients that are consistent but inefficient (Fameye et al., 2003; Fang, 2013). Greene (2003) therefore, proposed the use of ZINB to account for the over-dispersion problem under such circumstances. Over-dispersion in count data models arises when the variance of the scaler-dependent variable is larger than its mean (Winkelmann and Zimmermann, 1995; Winkelmann and Zimmermann, 1998).

In the ZIP model, the scaler dependent variable $\left(Y_{1}, Y_{2} \ldots \ldots \ldots \ldots \ldots \ldots \ldots \ldots \ldots Y_{n}\right)$ is independent and the assumption behind the model is that given a probability $(P)$, there are two possible outcomes; 0 and the probability of $\left(1-\pi_{i}\right)$ which leads to the generation of a Poisson random variable $(\lambda)$ in $Y_{i}$ (Cameron and Trivedi, 2013). The distribution of $Y_{i}$ is given as follows:

$Y_{i}=\left\{\begin{array}{l}0, \text { with probability } p_{i}+\left(1+\pi_{i}\right) e^{\left.-\lambda_{i}\right)} \\ k, \text { with probability }\left(1-\pi_{i}\right) \frac{e^{-\lambda_{i} \lambda_{i} y_{i}}}{y_{i}}, k=1,2,3 \ldots \ldots \ldots n\end{array}\right.$

The variance and mean of the zero inflated Poisson distribution are specified in (2) and (3), respectively;

$V\left(Y_{i}\right)=\left(1-\pi_{i}\right)\left(\lambda_{i}+\lambda^{2}{ }_{i}\right)-\left(\left(1-\pi_{i}\right) \lambda_{i}\right)^{2}$ 
$E\left(Y_{i}\right)=\left(1-\pi_{i}\right) \lambda_{i}$

Similar to ZIP, the ZINB also has two possible outcomes. Assume $\pi$ as the probability for the occurrence of case 1 which is zero and $(1-\pi)$ as the probability for case 2 which is a success. If $(1-\pi)$ occurs, the counts (including zeros) generated are line negative binomial model. In this case, Greene (1994) defined the probability of the ZINB random variable, $Y_{i}$ as;

$Y_{i}=0$ with probability $\pi_{i}$

$Y_{i} \sim$ negative binomial $\left(\lambda_{i}, \mathrm{k}\right)$ with probability $(1-\pi)$

This implies that,

$\operatorname{Pr}\left(Y_{i}=0\right)=\pi_{i}+\left(1-\pi_{i}\right)\left(1+k \lambda_{i}\right)^{-1 / k}$

$\operatorname{Pr}\left(Y_{i}=y_{i}\right)=\left(1-\pi_{i}\right) \frac{\Gamma\left(y_{i}+k^{-1}\right)}{\Gamma\left(k^{-1}\right) \Gamma\left(y_{i}+1\right)} \frac{\left(k \lambda_{i}\right)^{y_{i}}}{\left(1+k \lambda_{i}\right)^{\lambda_{i}+\frac{1}{k}}}, \quad y_{i}=1,2, \ldots \ldots \ldots . . .$.

From (5), the mean and variance of $y_{i}$ becomes:

$\left.V\left(Y_{i}\right)=\left(1-\pi_{i}\right) \lambda_{i} 1+\lambda_{i}\left(\pi_{i}+k\right)\right)$

$E\left(Y_{i}\right)=\left(1-\pi_{i}\right) \lambda_{i}$

where $\lambda_{i}$ denotes the mean of the negative binomial distribution with $k$ being the over-dispersion parameter. As $k \rightarrow 0$, the ZINB distributions reduces to the ZIP. Meanwhile, $\lambda_{i}$ is expressed as a function of linear predictor:

$\lambda_{i}=\exp \left(X_{i}^{\prime} \beta\right)$, where $\beta$ is a vector of unknown parameters to be estimated from the covariate vector $X_{i}{ }^{\prime}$ that would include farm and non-farm related factors that influence the extent of vertical integration of poultry farms. The main estimation procedure for (6) is using the method of maximum likelihood. As noted earlier, both ZIP and ZINB generate two models; first, the count model used to predict the response variable; and second, the inflated model used to predict the occurrence of the excess zeros.

\subsubsection{Model comparisons and selection}


Three tests of model fits were performed to compare and select the model that best explained the data (Table 1). First, the Akaike Information Criterion (AIC) (Akaike, 1973) and Bayesian Information Criterion (BIC) (Schwarz, 1978) tests were performed to score and select the appropriate model. However, while the AIC is asymptotically efficient but inconsistent, the BIC is consistent but not asymptotically efficient (Cavanaugh and Neath, 2019). In both instances, the model with the smallest value is considered the better fit. The Vuong test was also performed on the two models against the standard Poisson regression and negative binomial models.

Table 2 Model comparisons and selections

\begin{tabular}{lll}
\hline Test & Model & Decision rule \\
\hline AIC & AIC $=-2 \times \operatorname{In}($ likelihood $)+2 \times K$ & Choose model with smallest \\
& AIC value \\
BIC & AIC $=-2 \times \operatorname{In}($ likelihood $)+$ & Choose model with smallest \\
& $\operatorname{In}(N) \times K$ & BIC value \\
Voung test & - & Significant test statistic \\
& implies the data fits ZIP and \\
& ZINB against standard \\
& Poisson and Negative \\
& Binomial model, respectively. \\
\hline
\end{tabular}

Source: Cavanaugh and Neath (2019)

\subsubsection{Empirical model specifications}

Following the theoretical review of both the ZIP and ZINB, the empirical model guiding this study is specified as:

$$
\begin{aligned}
& Y_{i}=\beta 0+\beta 1(\mathrm{SEX})+\beta 2(\mathrm{EDU})+\beta 3(\mathrm{POCC})+\beta 4(\mathrm{FEXP})+\beta 5(\mathrm{AGE})+\beta 6(\mathrm{HHS})+ \\
& \beta 7(\text { EXTCON })+\beta 8(\mathrm{LANDOWN})+\beta 9(\mathrm{MFBO})+\beta 10(\text { TFSize })+\beta 11(\mathrm{TCOST})+ \\
& \beta 12(\mathrm{BTYPES})+\beta 13(\text { FOWN })+\beta 14(\text { ACCRDT })+\beta 15(\mathrm{TEMP})+\beta 16(\text { NONINC })+ \\
& \beta 17(\mathrm{TR})+\mu \mathrm{i}
\end{aligned}
$$

where $Y_{i}$ denotes the extent of vertical integration measure by the number of upstream and downstream activities expressed in percentages by the $i$ th farmer. The response variable $\left(Y_{i}\right)$ is hypothesized to contain excess zeros (inflated) and the reasons for such zeros to occur are different 
from the reasons for a poultry farm to participate in vertical integration. $\beta 1 \ldots \ldots \ldots \beta 17$ are the vector of parameters to be estimated, $\beta 0$ is the constant term, and $\mu \mathrm{i}$ the error term. In Table 3 are the descriptions and a priori expectations of the respondents, farm, and institutional variables included in the model. The explanatory variables adopted in this study were based on the findings from previous studies (Begum. 2005; Issa and Chrysostome, 2015; Harianto et al., 2019) across different agri-businesses in developing countries.

Table 3 Description of explanatory variables used for both ZIP and ZINP models

\begin{tabular}{|c|c|c|}
\hline Acronym & Codes / Description & $\begin{array}{l}\text { Expected } \\
\text { sign }\end{array}$ \\
\hline SEX & $\begin{array}{l}\text { Sex of poultry farmer, measured as a dummy variable }(1=\text { if farmer } \\
\text { is male and } 0=\text { otherwise })\end{array}$ & + \\
\hline EDUL & $\begin{array}{l}\text { Educational background of poultry farmer, measured as a } \\
\text { categorical variable }\left(1^{\mathrm{a}}=\text { No formal education, } 2=\text { Basic, }\right. \\
3=\text { Secondary, } 4=\text { Tertiary and above })\end{array}$ & + \\
\hline AGE & Age of poultry farmer, measured as a continuous variable in years & + \\
\hline HHSIZE & $\begin{array}{l}\text { Number of household size of poultry farmer, measured as a } \\
\text { continuous variable }\end{array}$ & + \\
\hline FEXP & $\begin{array}{l}\text { Poultry farmer experience, measured as a continuous variable in } \\
\text { years }\end{array}$ & + \\
\hline TEMP & $\begin{array}{l}\text { Number of employees of the poultry farm, measured as a } \\
\text { continuous variable }\end{array}$ & + \\
\hline NATOC & $\begin{array}{l}\text { Nature of occupation of farmer, measured as a dummy variable } \\
(1=\text { Full-time, } 0=\text { Part-time) }\end{array}$ & + \\
\hline MFBO & $\begin{array}{l}\text { Membership of poultry association, measured as a dummy variable } \\
(1=\text { member, } 0=\text { otherwise })\end{array}$ & + \\
\hline TCOST & $\begin{array}{l}\text { Total cost of poultry production, measured as continuous variable } \\
\text { (Gh } \varnothing / \text { layer) }\end{array}$ & - \\
\hline TFSize & $\begin{array}{l}\text { Total flock size, measured as a continuous variable (number of } \\
\text { birds) }\end{array}$ & + \\
\hline TR & $\begin{array}{l}\text { Total revenue of poultry farm, measured as a continuous variable } \\
(\mathrm{Gh} \phi / \text { spent layer and egg) }\end{array}$ & \\
\hline LANDOWN & $\begin{array}{l}\text { Land ownership, measured as a categorical variable }\left(1^{\mathrm{a}}=\right. \\
\text { family/inheritance, } 2=\text { Individual ownership } 3=\text { Lease } \\
\text { arrangement) }\end{array}$ & $+/-$ \\
\hline
\end{tabular}




\begin{tabular}{lll} 
FOWN & $\begin{array}{l}\text { Type of farm business ownership, measured as categorical variable } \\
\left(1^{\mathrm{a}}=\text { sole proprietorship, } 2=\text { family farm, } 3=\text { partnership }\right. \\
\text { arrangement })\end{array}$ \\
TBIRDS & $\begin{array}{l}\text { Types of birds managed, measured as categorical variable }\left(1^{\mathrm{a}}=\right. \\
\text { layer only, } 2=\text { broiler, } 3=\text { layer } \& \text { broiler })\end{array}$ \\
EXTCON & $\begin{array}{l}\text { Contact with extension agent measured as a dummy variable }(1= \\
\text { yes, } 0=\text { otherwise })\end{array}$ \\
ACCRT & $\begin{array}{l}\text { Access to credit/facilities and received loan, measured as dummy } \\
\text { variable }(1=\text { Have access, } 0=\text { Otherwise }\end{array}$ \\
NONINC & $\begin{array}{l}\text { Access to non-farm income sources, measured as a dummy variable } \\
(1=\text { Access, } 0=\text { Otherwise })\end{array}$ \\
\hline
\end{tabular}

a base category

\section{RESULT AND DISCUSSIONS}

\subsection{Extent of vertical integration in poultry business}

The extent of vertical integration is measured after taking the ratio of the poultry farm's auxiliary activities (besides the core production stage) to the total number of activities along the value chain (Table 4). The ratio is expressed in percentages (Figure 2) to depict the extent to which the poultry farms are vertically integrated. Out of the six (6) major auxiliary poultry value chain activities, 27 of the farms representing $64.3 \%$ own and operate their feed mills for mixing feeds. Similarly, about $54.8 \%$ owned delivery vans for both wholesale and retail delivery of eggs and chicken carcass within and outside the study's region. Besides, $42.9 \%$ of the respondents possess retail outlets in urban consuming centers to dispose of their eggs and birds directly to consumers. The data further shows a significant number $(38.1 \%)$ of the poultry firms managing their maize farms; the major feed ingredient representing $60 \%$ of compound feeds (USDA, 2017) used for both layers and broilers in the study zone. However, there were only one (2.4\%) and two (4.8\%) farms that have hatchery and processing houses, respectively. The absence of hatcheries to breed local day-old chicks is not uncommon since most poultry farms in Ghana prefer foreign day-old chicks from Europe compared with domestically hatched day-old chicks. According to Boschloo (2020), dayold chicks from Europe are hardy, disease-resistant, and could recover quickly after sickness 
compared with the domestically hatched chicks that are generally of low quality. In support, the GPP reported that more than 511,960 broiler and 7,130,999 layer day-old chicks are imported into Ghana on annual basis (USDA, 2017).

\section{Table 4 multiple responses of poultry farms participating in auxiliary poultry activities}

\begin{tabular}{lcc}
\hline Production stages & Frequencies & Percentage \\
\hline Own maize farm & 16 & 38.1 \\
Feed mill & 27 & 64.3 \\
Processing house & 2 & 4.8 \\
Hatchery & 1 & 2.4 \\
Delivery van for marketing & 23 & 54.8 \\
Retail outlet & 18 & 42.9 \\
Total & 87 & 207.1 \\
\hline
\end{tabular}

Source: Field data (2020)

Figure 2 shows the levels of vertical integration based on the classification by Misund (2016).

Nearly three-quarters (74\%) of the surveyed poultry farms fall below $20 \%$ of vertical integration and are classified as non-integrated farms. Partially integrated farms (21\% and 65\% of VI) represent $22 \%$ while fully vertically integrated farms are less than $5 \%$ in the study area. This finding agrees perfectly with the observations made by Bamiro and Shittu (2009) who reported significant non-integrated farms, but few full and partially vertically integrated poultry farms in Nigeria. The low degree of integration for the poultry farms may have a negative implication on the cost of production since farmers are likely to depend on intermediaries to source inputs (feeds, day-old chicks) and to dispose of the final products (egg and broiler meats). According to Begum (2005), high transaction and searching costs contribute to increasing the overall costs of producing poultry in developing economies. 


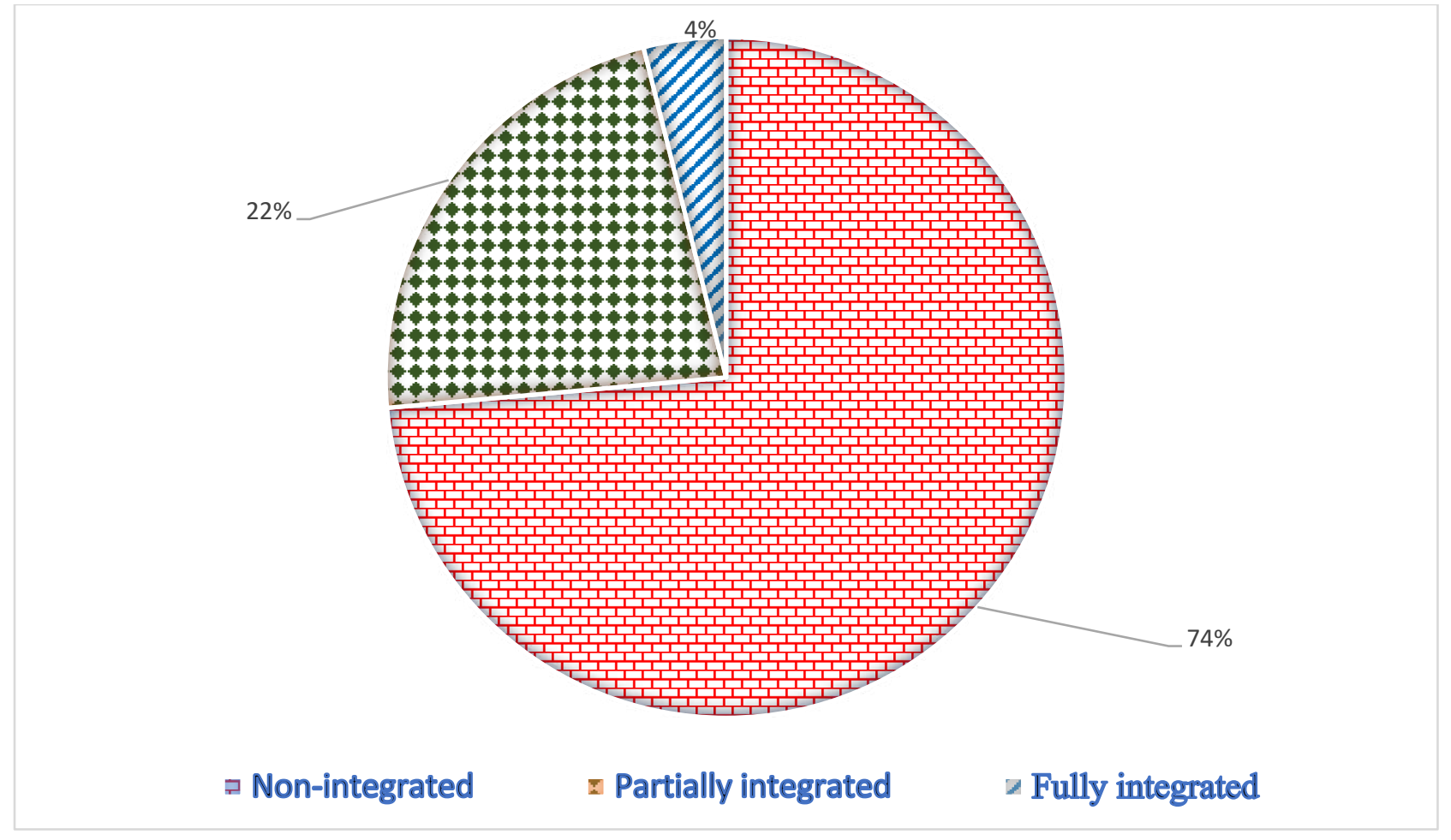

Figure 2 Levels of vertical integration among poultry farms

\subsection{Variable description according to extent of vertical integration}

Male farmers operate the majority $(69.6 \%)$ of the poultry farms, which is slightly lower than the 89.5\% reported by Adei and Asante (2012) in the same study municipality (Table 5). The low proportion of females in the poultry business may be attributed to the socio-cultural and economic constraints faced by women in establishing business ventures in developing economies (McPherson, 1992; Robinson \& Sexton, 1994; Presser \& Baldwin, 1980). The capital demand to set up and maintain poultry farms in sub-Sahara Africa is high, which turns to limit women participation in the livestock business. The high literacy rate of $52.9 \%$ of poultry farmers with more than senior high school certificates could have positive implications for the growth of the poultry business. This is because educated farmers can read and write which improves their ability to keep proper farm records, access information/credit, and adopt technologies to increase production. The literacy data is consistent with the $43.4 \%$ of poultry farmers with senior high 
school and tertiary certificates reported by Amoabeng (2011) in the same study area. Likewise, $78.4 \%$ of the poultry farmers are full-time workers, which emphasised that poultry farming is a major source of livelihood and thus can serve as a conduit for poverty reduction in the study area. This finding relates well with Bamiro et al (2009) who reported that over $50 \%$ of poultry farmers particularly in West African countries such as Nigeria are full-time workers.

Table 5 Description of variables used in econometric analysis

\begin{tabular}{|c|c|c|c|c|}
\hline Variables & $\begin{array}{l}\text { Non- } \\
\text { integrated } \\
(75)\end{array}$ & $\begin{array}{l}\text { Partially integrated } \\
\text { (23) }\end{array}$ & $\begin{array}{l}\text { Fully integrated } \\
\text { (4) }\end{array}$ & $\begin{array}{l}\text { Overall } \\
(102)\end{array}$ \\
\hline \multicolumn{5}{|l|}{ Discrete variables } \\
\hline \multicolumn{5}{|l|}{ Sex } \\
\hline $1=$ male & 62.7 & 91.3 & 75.0 & 69.6 \\
\hline $0=$ female & 37.3 & 8.7 & 25.0 & 30.4 \\
\hline \multicolumn{5}{|l|}{ Education } \\
\hline $1=$ No formal education & 10.7 & 8.7 & 50.0 & 11.8 \\
\hline $\begin{array}{l}\text { 2=Basic/Junior } \quad \text { High } \\
\text { School }\end{array}$ & 42.7 & 17.4 & 0.0 & 35.3 \\
\hline $\begin{array}{l}3=\text { Secondary/Senior High } \\
\text { School }\end{array}$ & 34.7 & 56.5 & 50.0 & 40.2 \\
\hline $4=$ Tertiary & 12.0 & 17.4 & 0.0 & 12.7 \\
\hline \multicolumn{5}{|l|}{ Nature of occupation } \\
\hline $1=$ Full time & 73.3 & 95.7 & 75.0 & 78.4 \\
\hline $0=$ Part-time & 26.7 & 4.3 & 25.0 & 19.6 \\
\hline \multicolumn{5}{|l|}{ Membership of association } \\
\hline $1=$ Yes & 80 & 100 & 100 & 85.3 \\
\hline $0=$ No & 20 & 0.0 & 0.0 & 14.7 \\
\hline \multicolumn{5}{|l|}{ Land acquisition } \\
\hline 1 = Family/inheritance & 68.9 & 30.4 & 75.0 & 60.4 \\
\hline $2=$ Individual ownership & 16.2 & 52.2 & 25.0 & 24.8 \\
\hline $3=$ Lease arrangement & 14.9 & 17.4 & 0.0 & 14.9 \\
\hline \multicolumn{5}{|l|}{$\begin{array}{l}\text { Type of farm business } \\
\text { ownership }\end{array}$} \\
\hline $1=$ Sole proprietorship & 78.7 & 82.6 & 100.0 & 80.4 \\
\hline $2=$ Family farm & 21.3 & 13.0 & 0.0 & 18.6 \\
\hline $\begin{array}{l}3 \quad=\quad \text { Partnership } \\
\text { arrangement }\end{array}$ & 0.0 & 4.3 & 0.0 & 1.0 \\
\hline \multicolumn{5}{|l|}{$\begin{array}{l}\text { Extension/veterinary } \\
\text { contact }\end{array}$} \\
\hline $1=$ Yes & 83.8 & 43.5 & 50.0 & 76.2 \\
\hline $0=$ No & 16.2 & 56.5 & 50.0 & 23.8 \\
\hline $\begin{array}{l}\text { Access to credit } \\
1=\text { Yes }\end{array}$ & 36.0 & 87.0 & 100 & 50.0 \\
\hline
\end{tabular}




\begin{tabular}{|c|c|c|c|c|}
\hline $0=$ No & 64.0 & 13.0 & 0.0 & 50.0 \\
\hline Access to non-farm income & & & & \\
\hline $1=$ Yes & 32.0 & 13.0 & 25.0 & 27.5 \\
\hline $0=$ No & 68.0 & 87.0 & 75.0 & 72.5 \\
\hline Continuous variables & \multicolumn{4}{|c|}{ Compare means (ANOVA) } \\
\hline Age of poultry farmer & $49.25(11.53)$ & $53.83(7.02)$ & $50.50(11.03)$ & $50.33^{\mathrm{ns}}$ \\
\hline Household size & $5.19(2.25)$ & $6.83(1.64)$ & $6.0(2.58)$ & $5.9 * * *$ \\
\hline Farming Experience & $6.60(5.36)$ & $10.09(6.02)$ & $11.0(4.23)$ & $7.52 * *$ \\
\hline Number of employees & $2.19(0.95)$ & $5.35(2.29)$ & $10.5(2.74)$ & $6.01 * * *$ \\
\hline $\begin{array}{l}\text { Total cost of poultry } \\
\text { production }(\mathrm{Gh} \phi / \text { bird })\end{array}$ & $68.61(16.46)$ & $65.32(6.76)$ & $63.08(8.24)$ & $67.65^{* * *}$ \\
\hline Total flock size & $3,568(2782)$ & $12,631.74(54.35 .48)$ & $14,675(7063.22)$ & $6,047 * *$ \\
\hline Total revenue (Ghф/bird) & $138.53(24.9)$ & $178.10(56.70)$ & $209.63(66.60)$ & $199.73 * * *$ \\
\hline
\end{tabular}

The high FBOs membership of $85.3 \%$ presupposes that, through the leadership, the members can have access to reliable information and productive resource to improve poultry production/productivity. This data is consistent with the report by Nimoh et al. (2013) that the majority $(82 \%)$ of the poultry farmers in Ghana belongs to farmer group organizations. Family/lineage inheritance remains the dominant (60.4\%) means of land acquisition in the area. This buttresses the report by Adams and Ohene-Yankyera (2014) that agricultural lands in Ghana are mainly acquired through family lineage. However, a majority $(80.4 \%)$ of the farms are owned through sole proprietorship against a few which are under family or partnership arrangement. This finding corroborates with Bamiro and Shittu (2009) who reported that $79.1 \%$ of poultry farms in Nigeria are operated through sole proprietorship. On extension/veterinary access, more than threequarter have access to extension/veterinary services. Such high access has a positive impact on poultry production since extension/veterinary technical staff are responsible for the dissemination of technologies and the provision of technical advice for improved production. About half (50\%) of the respondents have access to credit and $72.5 \%$ do not have access to non-farm income sources. Having access to credit could afford the poultry farmers the opportunity to expand or maintain 
their farms and improve productivity. The average age of 50.33 years is an indication of an industry populated by the aged. This calls for a consented effort by the government and other stakeholders to introduce packages that will lure the youth into poultry production. This data contradicts Folitse et al. (2018) who observed a relatively younger (31 and 40 years) poultry farmer population in Greater Accra region of Ghana.

The respondents have higher experience as depicted by the 7.5 years of poultry farm management. Across the extent of vertical integration, farmers who operate fully vertically integrated farms (11.0) dominate before partially integrated farmers (10.09) and finally no integrated farms (6.60). Similarly, the data shows a significant number of employees (10.5), flock size $(14,675)$, and revenue (Ghф209.63) for farmers who operate fully vertically integrated farms compared to their counterparts with partially and no integrated farms. These statistics relate well with the findings of Bamiro et al. (2009) who reported higher returns and flock size for farmers with vertically integrated poultry farms in Nigeria. Further, the cost incurred is also lower for vertically integrated poultry farms (Ghф63.08) compared with partially integrated (Ghф65.32) and no integration farms (Ghф68.61). The results agree well with the findings of Buzzel (1983) and Bamiro et al. (2009) who conclude that vertical integration leads to cost reduction, which, in turn, increases investors' investments.

\subsection{Parameter estimates from ZIP and ZINB regression models}

The coefficients of both zero-inflated Poisson and zero-inflated negative binomial regressions are summarised in Table 6 and Table 7, respectively. The results of the ZIP model show 16 out of the 20 covariates significantly influence the extent of vertical integration among poultry farms. On the other hand, 14 of the 20 explanatory variables in the ZINB are considered as predictors of vertical integration of poultry farming. A large proportion of explanatory variables in the ZIP model are 
significant compared with the ZINB because the standard errors in the ZIP model are underestimated. This finding is congruent with the study of Yusuf et al. (2018) who reported an overestimated standard error in ZINB in relation to ZIP models. In Table 8, various tests were computed to compare and select the best model that describes that data. First, the Voung tests for both models are significant at $1 \%$ significance level, which implies that the data perfectly fits ZIP and ZINB due to the excess zeros instead of the standard Poisson and negative binomial models, respectively. However, the sample mean (0.95) of the response variable (extent of vertical integration) is less than the sample variance of 1.82, which suggests the case of over-dispersion in the data. Similarly, the AIC (443.38) and BIC (506.11) values for the ZINB model are positive and lower than the AIC (456.69) and BIC (519.22) values reported in the ZIP regression. The forgoing tests demonstrate that the ZINB is the most appropriate model to examine the determinants of vertical integration of poultry production in event of data with over-dispersion and inflated zeros. Therefore, the significant predictors of vertical integration in poultry production were evaluated (Table 8). The coefficients of the estimated parameters are reported in odds ratios - exp (coefficient) - similar to the coefficient interpretation of the standard Poisson regression model (See UCLA, 2020).

Table 6 Coefficients of factors in the zero-inflated Poisson regression model

\begin{tabular}{|c|c|c|c|c|c|c|}
\hline \multirow[b]{2}{*}{ Variable } & \multicolumn{3}{|c|}{$\begin{array}{c}\text { Count model } \\
\end{array}$} & \multicolumn{3}{|c|}{ Inflation model } \\
\hline & $\operatorname{Coef}(\beta)$ & $\operatorname{SE}(\beta)$ & Z-test & $\operatorname{Coef}(\beta)$ & $\mathrm{SE}(\beta)$ & Z-test \\
\hline \multicolumn{7}{|l|}{ Personal characteristics } \\
\hline Age of farmer & 0.0051 & 0.0048 & 1.06 & -0.0067 & 0.1319 & -0.05 \\
\hline Sex & 0.2541 & 0.1140 & $2.22 * *$ & -0.9190 & 3.263 & -0.28 \\
\hline Household size & -0.0209 & 0.0217 & -0.97 & -1.5011 & 0.8167 & $-1.84 *$ \\
\hline Education level & & & & & & \\
\hline $\begin{array}{l}\text { Completed Basic/Junior } \\
\text { High School }\end{array}$ & 0.4186 & 0.1143 & $3.66 * * *$ & -0.630 & 0.369 & $-1.76^{*}$ \\
\hline $\begin{array}{l}\text { Completed Senior High } \\
\text { School }\end{array}$ & 0.2381 & 0.0728 & $3.27 * * *$ & -0.6080 & 0.2781 & $-2.19 * *$ \\
\hline $\begin{array}{l}\text { Completed Tertiary } \\
\text { Education }\end{array}$ & 0.3101 & 0.1125 & $2.78 * *$ & -1.4627 & 3.0746 & -0.48 \\
\hline Non-farm income & 0.0770 & 0.1160 & 0.66 & -2.8042 & 4.2678 & -0.66 \\
\hline
\end{tabular}




\begin{tabular}{|c|c|c|c|c|c|c|}
\hline Nature of occupation & 0.2793 & 0.1339 & $2.09 * *$ & -0.6780 & 0.244 & $-2.47 * *$ \\
\hline Farm experience & 0.0127 & 0.0071 & $1.70^{*}$ & 0.5394 & 0.2552 & $2.11 * *$ \\
\hline \multicolumn{7}{|l|}{ Farm characteristics } \\
\hline \multicolumn{7}{|l|}{ Land ownership } \\
\hline Individual ownership & 0.1190 & 0.0622 & $1.91 *$ & -3.945 & 4.656 & -0.85 \\
\hline Lease agreement & 0.0311 & 0.1377 & 0.23 & -1.2073 & 3.1855 & -0.38 \\
\hline Flock size & 0.0076 & 0.0010 & $7.21 * * *$ & 0.0011 & 0.0006 & $1.93 *$ \\
\hline Production cost & -0.0327 & 0.0065 & $-4.97 * * *$ & 0.2358 & 0.1087 & $2.11 * *$ \\
\hline Revenue per bird & 0.0023 & 0.0010 & $2.23 * *$ & -0.0864 & 0.0515 & $-1.68 *$ \\
\hline \multicolumn{7}{|c|}{ Type of farm business ownership } \\
\hline Family farm & -0.3113 & 0.0971 & $3.21 * * *$ & -0.758 & 0.403 & $-1.88 *$ \\
\hline Partnership & -0.485 & 0.2172 & $2.23 * *$ & -0.1970 & 0.1173 & $-2.53 * * *$ \\
\hline Employee size & 0.1039 & 0.0254 & $4.10 * * *$ & -3.520 & 2.069 & $-1.70 *$ \\
\hline \multicolumn{7}{|c|}{ Institutional characteristics } \\
\hline Access to credit & 0.4201 & 0.0994 & $4.23 * * *$ & -0.944 & -0.560 & $1.68 *$ \\
\hline Extension service & 0.2426 & 0.0819 & $2.96 * * *$ & 7.478 & 4.643 & 1.61 \\
\hline Association membership & 0.2466 & 0.0852 & $2.89 * * *$ & 8.1047 & 4.0373 & $2.01 * *$ \\
\hline Constant & 5.105 & 0.6238 & $1.84 *$ & 44.664 & 24.994 & $1.79^{*}$ \\
\hline \multicolumn{7}{|l|}{ Model diagnostics } \\
\hline Number of observations & & & & & & 100 \\
\hline Non-zero observations & & & & & & 44 \\
\hline LR chi-square (21) & & & & & & $386.21 * * *$ \\
\hline Inflation model & & & & & & Logit \\
\hline Log-likelihood & & & & & & -175.54 \\
\hline
\end{tabular}

Table 7 Coefficients of factors in the zero-inflated negative Binomial regression model

\begin{tabular}{|c|c|c|c|c|c|c|}
\hline & \multicolumn{3}{|c|}{ Count model } & \multicolumn{3}{|c|}{ Logit for inflation model } \\
\hline Variable & $\operatorname{Coef}(\beta)$ & $\mathrm{SE}(\beta)$ & Z-test & $\operatorname{Coef}(\beta)$ & $\mathrm{SE}(\beta)$ & Z-test \\
\hline \multicolumn{7}{|l|}{ Personal characteristics } \\
\hline Age of farmer & 0.0034 & 0.0070 & 0.49 & 0.0065 & 0.1318 & 0.05 \\
\hline Sex & 0.1849 & 0.2025 & 0.91 & 0.9170 & 3.2600 & 0.28 \\
\hline Household size & -0.019 & 0.0326 & -0.59 & -1.488 & 0.8153 & $-1.83 *$ \\
\hline Education level & & & & & & \\
\hline $\begin{array}{l}\text { Completed Basic/Junior } \\
\text { High School }\end{array}$ & 0.4059 & 0.1709 & $2.38 * *$ & -0.628 & 0.3570 & $-1.75^{*}$ \\
\hline $\begin{array}{l}\text { Completed Senior High } \\
\text { School }\end{array}$ & 0.222 & 0.1214 & $1.83 *$ & -0.5970 & 0.2771 & $-2.15 * *$ \\
\hline $\begin{array}{l}\text { Completed Tertiary } \\
\text { Education }\end{array}$ & 0.3184 & 0.1778 & $1.79 *$ & -1.3891 & 3.0535 & -0.45 \\
\hline Non-farm income & 0.1025 & 0.1668 & 0.61 & 2.6840 & 4.1567 & 0.64 \\
\hline Primary Occupation & 0.2657 & 0.1857 & $3.10 * * *$ & -0.5375 & 0.2462 & $-2.18 * *$ \\
\hline Farm experience & 0.0306 & 0.011 & $2.70 * * *$ & 0.5394 & 0.2552 & $2.11 * *$ \\
\hline $\begin{array}{l}\text { Farm characteristics } \\
\text { Land ownership }\end{array}$ & & & & & & \\
\hline Individual ownership & 0.255 & 0.1235 & $2.06 * *$ & -2.895 & 3.7870 & -0.76 \\
\hline Lease agreement & -0.0364 & 0.196 & -0.19 & -1.154 & 3.1640 & -0.36 \\
\hline Flock size & 0.0074 & 0.0015 & $4.93 * * *$ & 0.0011 & 0.0006 & $1.93 *$ \\
\hline
\end{tabular}




\begin{tabular}{|c|c|c|c|c|c|c|}
\hline Production cost & -0.0290 & 0.0095 & $-3.06 * * *$ & 0.2247 & 0.1077 & $2.08 * *$ \\
\hline Revenue per bird & 0.0028 & 0.0012 & $2.4 * *$ & -0.0834 & 0.0514 & $-1.62 *$ \\
\hline \multicolumn{7}{|c|}{ Type of farm business ownership } \\
\hline Family farm & 0.2701 & 0.1485 & $1.82 *$ & 0.6891 & 0.4020 & $1.71 *$ \\
\hline Partnership & 0.2698 & 0.1236 & $2.4 * *$ & -0.1970 & 0.1173 & $-1.68^{*}$ \\
\hline Employee size & 0.089 & 0.038 & $2.32 * *$ & -3.520 & 2.0690 & $-1.70^{*}$ \\
\hline \multicolumn{7}{|c|}{ Institutional characteristics } \\
\hline Access to credit & 0.3540 & 0.1525 & $2.32 * *$ & -0.921 & -0.550 & $1.67 *$ \\
\hline Extension service & 0.2612 & 0.1288 & $2.03 * *$ & 7.388 & 4.5330 & 1.62 \\
\hline Association membership & 0.2980 & 0.1570 & $1.89 *$ & 8.047 & 4.0030 & $2.01 * *$ \\
\hline Constant & 4.761 & 0.9180 & $5.18 * * *$ & 44.078 & 24.437 & $1.80^{*}$ \\
\hline \multicolumn{7}{|l|}{ Model diagnostics } \\
\hline Number of observations & & & & & & 100 \\
\hline Non-zero observations & & & & & & 44 \\
\hline LR chi-square (21) & & & & & & $69.16 * * *$ \\
\hline Inflation model & & & & & & Logit \\
\hline Log likelihood & & & & & & -165.84 \\
\hline
\end{tabular}

Table 8 model comparisons and selections

\begin{tabular}{lll}
\hline Test & ZIP & ZINB \\
\hline AIC & 456.692 & 443.58 \\
BIC & 519.216 & 506.11 \\
Vuong test & $5.26^{* * *}$ & $3.09 * * *$ \\
Mean (variance) of response variable & $0.95(1.82)$ \\
\hline
\end{tabular}

\subsection{Count data component of the ZINB model}

\subsubsection{Personal characteristics}

The educational background of the poultry farmer was positively and significantly related to the extent of vertical integration of poultry production. For instance, the extent of vertical integration for a farmer with Basic/Junior High School certificate is likely to increase exp $(0.4059)=1.5$ times compared with a farmer without formal education, all things being equal. Similarly, there was a higher odds ratio for farmers with Senior High School (1.24 times) and Tertiary education (1.37 times) to vertically integrate their poultry farms compared with non-educated counterparts, all things being equal. The results agree with Bamiro et al. (2009) who found out that the educational 
background of poultry farmers is important for vertical integration of poultry farms in Nigeria. In a related study for Rwanda, Issa and Chrysostome (2015) (2014) also concluded that education is a predetermined factor to integrate agro-businesses in developing economies. Similarly, the primary occupation of the poultry farmer positively influences the extent of vertical integration of poultry farms at a $1 \%$ significance level. The results imply that full-time poultry farmers are more likely to vertically integrate their poultry farms $\exp (0.2657)=1.30$ times compared with part-time poultry farmers, all things being equal. Likewise, poultry farmers with higher farming experience are $\exp (0.0306)=1.031$ times more likely to participate in the vertical integration of poultry farms. The latter finding is in line with Elzo et al. (2010) who argued that experienced farmers tend to accumulate managerial skills over the years to better manage the complexities associated with different production stages under the same management units of a business as in the case of vertical integration. The finding relates well with Bamiro et al. (2009) who reported a significant positive relationship between poultry farmer's experience and the degree of vertical integration.

\subsubsection{Farm characteristics}

The type of land ownership tends to significantly influence the extent of vertical integration of poultry farms in the study area. For instance, the extent of vertical integration is expected to increase $\exp (0.255)=1.29$ times for farmers with full property rights of farmland than farmers with family/inherited farmlands. This finding supports the assertions made by Awudulai et al. (2008) who observed that owner-operated with full rights of farmland is more likely to increase investments in other activities of farm to reduce the overall cost of farm production, thereby increasing profitability in Ghana. Likewise, increases in flock size and revenue would increase the degree of vertical integration by factors of $\exp (0.0074)=1.007$, and $\exp (0.0028)=1.003$, respectively, all things being equal. The result on flock size is similar to the findings of Issa and 
Chrysostome (2015) who documented a significant positive relationship between farm size and the capacity to vertically integrate agribusinesses in Rwanda. Likewise, Elzo (2010) asserts that agribusinesses with higher revenue tend to record higher profitability and as such, such businesses will have enough funds for investments in other activities that increase overall firm performance. However, the data shows that increases in overall production costs are expected to decrease the extent of vertical integration by a factor of $\exp (-0.0290)=0.97$, all things being equal. This finding according to Kusi et al. (2015) partly explains the low vertical integration among poultry farms in Ghana. This is so because the high cost of production leads to low profitability of the poultry business, which eventually generates little or no extra funds to invest in other activities along the poultry value chain.

\subsubsection{Institutional characteristics}

Access to institutional factors such as credit facilities, extension contact, and membership of poultry farm association are well recognized to create the enabling environment for investment and expansion of existing businesses (Essel et al., 2018). The data shows that the extent of vertical integration for farmers with access to credit facilities is expected to increase by $\exp (0.354)=1.42$ times compared to farmers without credit access, all things being equal. This finding corroborates with de-Janvry et al. (2005) who noted that access to credit/loan improves the liquidity capacity of the farm; helps smoothen capital fluctuations, and thus facilitates investments in other activities that improve overall business performance. In terms of extension contact and membership of poultry association, the results depict that the extent of vertical integration for farmers with extension contact and membership of poultry association is expected to increase by exp $(0.2612)$ $=1.26$ times and $\exp (0.2980)=1.37$ times, respectively, all things being equal. These findings did not deviate from the observations made by Marinda et al. (2006) who reported that the 
production and marketing landscape of agricultural products is evolving fast, and this requires the collection and processing of information to gain competitive advantage and expand on-farm investments. Thus, farmers with improved extension service contact and membership of associations tend to be abreast with improved farming technologies and can access credit facilities for more farm investments to achieve higher profitability.

\subsubsection{The logit inflation model}

The inflation component of the ZINB predicts the occurrence of the excess zeros of the model (Table 7). The data shows that farmer personal factors such as education, primary occupation, and household size decreases the likelihood of absolute zeros while farming experience increases the incidences of absolute zeros. For instance, the odds of being in absolute zero categories for farmers with Junior and Senior High School certificates are expected to decrease by $\exp (-0.628)=0.53$ times and $\exp (-0.5970)=0.55$ times, respectively all things being equal. Similarly, the odds of being in the absolute zero groups for full-time poultry farmers are expected to decrease by exp ($0.538)=0.53$ times. In other words, farmers with some form of education who are full-time poultry farmers are less likely to contribute to the excess zeros in the vertical integration of poultry farms. However, an increase in farming experience is likely to increase the odds of being in the absolute zero categories by $\exp (0.5394)=1.71$.

In terms of poultry farm-related factors, whiles the odds of a certain zero is lower for farms with higher flock size, employee size, and revenue, the odds are higher for farms with a high cost of production. The results also show a higher odds ratio for farmers with full outright ownership of land compared to family/inheritance ownership, all things being equal. The result implies that increasing flock size, employee size, revenue with full outright land ownership contribute less to 
being part of the absolute zeros in assessing vertical integration in poultry production. However, a higher cost of production predisposes farmers to belong to the excess zero categories.

The study shows two institutional factors including credit access and association membership significantly influence the absolute zeros of vertical integration. The data shows a lower odds ratio for farmers with credit access to be part of the absolute zeros categories in examining vertical integration of poultry production. On the contrary, access to association membership tends to increase the odds of poultry farmers belonging to the absolute zero groups.

\section{CONCLUSION}

Over the past decades, the poultry industry in sub-Sahara Africa has declined due to the high cost of production. Strategies that enhance the vertical integration of poultry farms would greatly influence transaction costs, risks, and uncertainties as well as demand variations, which ultimately improves the competitiveness of the sector for higher farmer returns. However, little is known about the implications of vertical integration in the poultry sector, particularly in Ghana. This study, therefore, examines vertical integration in poultry production using econometric models that provide findings with serious implications for the development of the poultry industry. The study contributes to existing agribusiness management literature by exploring critical factors that influence the vertical integration of poultry farms, particularly in Ghana.

Given that previous studies on the measurement of vertical integration in poultry production are simplistic and inconclusive, this study uses vertical integration index to accurately and sufficiently capture the extent of vertical integration in the industry. The study evidences that institutional factors such as membership of poultry associations, extension education, and access to credit are important precursors of vertical integration among poultry farms. This finding has implications to 
strengthen existing poultry associations through periodic capacity building programs for both leadership and members. This is even more important because the study shows a significant relationship between farmer's characteristics such as formal education and the decision to participate in the vertical integration of poultry farms. To complement this effort, special concessionary credit facilities could be made available to members of these associations for diversification of investments along the poultry value chain. Second, the significant effect of farm factors such as costs of production on vertical integration of poultry business demands subsidy or elimination of import duties on critical poultry inputs such as day-old chicks and medications into the country. Lastly, the study shows that the ZINB model best describes the determinant of vertical integration for data with excess zeros and over-dispersion. Therefore, it is highly recommended to use objective criteria in choosing appropriate econometric models to analyse count data problems that are zero-inflated and over-dispersed.

\subsection{DECLARATIONS}

\section{Availability of data and material}

The datasets used and/or analysed during the current study are available from the corresponding author on reasonable request.

\section{Competing interest}

The authors declare that they have no competing interest

\section{Funding}

Not applicable

\section{Ethics approval and consent to participate}

Not applicable

\section{Consent for publication}

All authors sanctioned the manuscript publication

\section{Authors' Contribution}

FA wrote the proposal, collected the data, did the analysis, and wrote the paper. AM also participated in the data collection and performed the analysis. SE, RA and JOM edited and reviewed the manuscript. All the authors read and approved the manuscript for publication. 


\section{Acknowledgement}

The authors highly appreciate the support of the undergraduate students of Agribusiness Management, 2020 batch who participated in the collection of data for this study.

\section{REFERENCE}

Adams F, Ohene-Yankyera K 2014 Socio-economic characteristics of subsistent small ruminant farmers in three regions of Northern Ghana, Asian Journal of Applied Science and Engineering, 3(3): 351-364.

Adei D, Asante BK 2012 The challenges and prospects of the poultry industry in Dormaa district. Journal of Science and Technology, 32(1): 104-116. http://doi: 10.4314/just.v32i1.11

Adelman MA 1955 Concept and statistical measurement of vertical integration. In: G.J. Stigler (ed), Proceedings of business concentration and price policy: A Conference of the Universities. National Bureau Committee for Economic Research. pp. 281-330.

Akaike H (1973) Information theory and an extension of the maximum likelihood principle. In: BN Petrov, F Csáki (eds.) 2nd international symposium on information theory (pp. 267281). Budapest, Hungary: Akadémia Kiadó

Amaobeng E 2011 Financial management knowledge among entrepreneurs in the poultry industry: a case of the Dormaa municipality (Unpublished Master thesis), Submitted to Kwame Nkrumah University of Science and Technology, Kumasi-Ghana.

Anang BT, Yeboah C, Agbolosu A. 2013 Profitability of broiler and layer production in the Brong Ahafo region of Ghana. Asian Research. Publishing Network Journal of Agriculture and Biological Science, 8(5): 423-430 
Atuahene CC, Attoh-Kotoku V, Mensah JJ 2010 Poultry production in Ghana: prospects and challenges. Ghana Journal of Animal Science, 5(2): 93-99.

Awudulai A, Owusu V, Goetz R., 2020 Property rights and investment in agriculture: Evidence for Ghana. MPRA Paper No. 37046. Available at https://mpra.ub.unimuenchen.de/37046/, accessed on $27^{\text {th }}$ December, 2020.

Bamiro OM, Dayo OAP, Momoh S, 2006 Vertical integration and technical efficiency in poultry (egg) industry in Ogun and Oyo States, Nigeria. International Journal of Poultry Science, 5(12):1164-1171.

Bamiro OM, Olanrewaju OA, Olubanjo A, 2012 Economics of Horizontal Integration in poultry industry in South-West Nigeria. International Journal of Poultry Science, 11(1): 39-46.

Bamiro OM, Shittu AM, 2009 Vertical integration and cost behaviour in poultry industry in Ogun and Oyo States of Nigeria, Agribusiness, 21(1):1-15.

Barrera-Ray F, 1995 The effects of vertical integration on oil company performance. Oxford Institute for Energy Studies. WPM 21. Accessed on October, 2020, available at www.oxfordenergy.org.

Basant R, Mishra P, 2017 Vertical integration, market structure and competition policy: experiences of Indian manufacturing sector during the post-reform period, W.P. No. 201709-02.

Baum EL 1951 An evaluation of integration in the poultry meat industry. Journal of Farm Economics, 33:1034-37.

Begum IA 2005 Vertically integrated contract and independent poultry farming system in Bangladesh: a profitability analysis. Livestock Research for Rural Development. 17: 
Article \#89. Retrieved February $\quad$ 10, 2021, from http://www.lrrd.org/lrrd17/8/ara17089.htm.

Benmehaia AM, Brabez F, 2016 Empirical factors determining vertical integration in Algerian Food manufacturing sector, European Scientific Journal, 12(28):ISSN 1857-7881. http://doi: 10.19044/esj.2016.v12n28p252

Boschloo R 2020 Analysis poultry sector Ghana 2019: An update on the opportunities and challenges. Embassy of the Kingdom of the Netherlands, Accra-Ghana.

Buzzell RD 1983 Is vertical integration profitable? Harvard Business Review, 61:92-102.

Cameron AC, Trivedi PK 2013 Regression Analysis of Count Data. 2nd Edition, (Cambridge University Press, New York)

Carlton D, Perloff J, 2005 Modern Industrial Organization (4th Ed), (Pearson Addison Wesley, Boston).

Cavanaugh JE, Neath AA, 2019 The Akaike information criterion: Background, derivation, properties, application, interpretation, and refinements. WIREs Comput Stat. 2019;11:e1460. https://doi.org/10.1002/wics.1460

Chapman S, Ashton T 1914 The size of business mainly in the textile industries. Journal of the Royal Statistical Society: 469-549.

Coase RH 1937 The Nature of the Firm, Economica. 4: 386-405.

de Janvry, A., Sadoulet, E. and Zhu, N. 2005. The role of non-farm incomes in reducing rural poverty and inequality in China. Department of Agricultural and Resource Economics, UCB, UC Berkeley. 
Diallo A, Diop A, Dupuy F 2019 Estimation in zero-inflated binomial regression with missing covariates. Statistics A Journal of Theoretical and Applied Statistics, 53(4): 839-865. doi.10.1080/02331888.2019.1619741. hal-01585220

Diallo AO, Diop A, Dupuy JF, 2017 Asymptotic properties of the maximum likelihood estimator in zero-inflated binomial regression. Communications in Statistics - Theory and Methods, doi 10.1080/03610926.2016.1222437.

Diop A, Diop A, Dupuy JF 2016 Simulation-based inference in a zero-inflated Bernoulli regression model. Communications in Statistics - Simulation and Computation, 45(10), 3597-3614.

Elzo A, Suwanasopee T, Yeamkong S, Koonawootrittriron S 2010 Effect of Experience, Education, Record, labour and Decision Making on Monthly Milk Yield and Revenue of Dairy Farms Supported by a Private Organization in Central Thailand. Asian- Aust. J. Anim. Sci. 23(2): 814-824.

Essel BKC, Adams F, Amankwah K 2019 Effect of entrepreneur, firm, and institutional characteristics on small-scale firm performance in Ghana. Journal of Global Entrepreneurship Research, 9: 55.

Etuah S, Ohene-Yankyera K, Liu Z, Mensah JO, Lan J 2020 Determinants of cost inefficiency in poultry production: evidence from small-scale broiler farms in the Ashanti region of Ghana, Tropical Animal Health and Production, 52:1149-1159.

Fameye F, John TW Karan PS 2003. On the generalized Poisson regression model with an application to accident data. Journal of Data Science, 2: 287-295.

Fang R 2013. Zero-inflated negative binomial (ZINB) regression model for over-dispersed count data with excess zeros and repeated measures: an application to human microbiota sequence data (Master's thesis, North China Coal Mining Medical College). Retrieved 
from

https://dspace.library.colostate.edu/.../FANG_ucdenveramc_1639M_10037.pdf?seque

FAOSTAT 2019 Statistical data.Food and Agriculture Organization of the United Nations, Rome.

Food and Agriculture Organization [FAO] 2010 Smallholder poultry production - livelihoods, food security and sociocultural significance. FAO Smallholder Poultry Production No. 4. Rome.

Garay AM, Hashimoto EM, Ortega EMM, Lachos VH 2011 On estimation and influence diagnostics for zero-inflated negative binomial regression models, Computational Statistics \& Data Analysis, 55(3): 1304-1318.

Global Agricultural Information Network [GAIN] (2017) 2017 Ghana Poultry Report Annual. Accessed at at https://apps.fas.usda.gov/newgainapi/api/report/downloadreportbyfilename?filename=20 17\%20Ghana\%20Poultry\%20Report\%20Annual\%20_Accra_Ghana_5-23-2017.pdf

Gort M 1962 Diversification and Integration in American Industry, (USA, Princeton University Press).

Greene WH 2003 Econometric Analysis, Sixth $\left(6^{\text {th }}\right)$ Edition, (New York University Prentice Hall, New York, USA).

Greene WH 1994 Accounting for excess zeros and sample selection in Poisson and negative binomial regression models. Working Paper, Department of Economics, Stern School of Business, New York University, New York.

Grega L 2003 Vertical integration as a factor of competittiveness in agriculture. Agric. Econ.Czech, 49(11): 520-525 
Guèye EHF 2000 Women and family poultry production in rural Africa. Development in Practice, 10(1): 98-102.

Hamdaoui M, Bouayad B 2019 Determinants and effects of vertical integration on the performance of Moroccan manufacturing, Athens Journal of Mediterranean Studies, 5(1):57-78. doi=10.30958/ajms.5-1-4

Hariantoa KN, Paramita DA 2019. The impact of vertical integration intensity on broiler farms technical efficiency: the case of contract farming in west Sumatera, Tropical Animal Science Journal 42(2):167-174.

Isaksen JR, Dreyer B, Grønhaug K, 2002 Vertical integration towards different sources of raw material. In: O Solem (ed.), Norway (PDF) Effect of Vertical Integration on the Performance of Agricultural Commodity Business. Case Study of Export Trading $\begin{array}{lll}\text { Company } & \text { Ltd. Available from: }\end{array}$ https://www.researchgate.net/publication/313468607_Effect_of_Vertical_Integration_on _the_Performance_of_Agricultural_Commodity_Business_Case_Study_of_Export_Tradi ng_Company_Ltd [accessed Dec 11 2020].

Issa N, Chrysostome NJ 2015 Determinants of farmer participation in the vertical integration of the Rwandan coffee value chain: results from Huye district. Journal of Agricultural Science, 7(9): ISSN 1916-9752.

Kaiser F, Obermaier R 2020 Vertical (Dis-) Integration and firm performance: A management paradigm revisited. Schmalenbach Bus. Rev., 72:1-37.

Kusi LY, Agbeblewu S, Anim IK, Nyarku KM 2015 The challenges and prospects of the commercial poultry industry in Ghana: A Synthesis of Literature. International Journal of Management Sciences, 5(6): 476-489. 
Lambert D 1992. Zero-inflated Poisson regression, with an application to defects in manufacturing, Technometrics, 34(1):1-14. https://doi.org/10.2307/1269547

Lewsey JD, Thomson WM 2004 The utility of the zero-inflated Poisson and zero-inflated negative binomial models: a case study of cross-sectional and longitudinal DMF data examining the effect of socio-economic status. Community Dent Oral Epidemiology, 32: 183-9.

Luciana MV 2008 The applicability of transaction costs economics to vertical integration decision: evidences from a Brazilian beef processor, Organizações Rurais \& Agroindustriais, 10(3): $317-327$

Maddigan R 1981 The measurement of vertical integration. Review of Economics and Statistics, 63(3): 328-335.

Marinda P, Bangura A, Heidhues F 2006 Technical efficiency analysis in male and femalemanaged farms, a study of maize production in West Pokot district, Kenya', Paper Presented at the Poster paper prepared for Presentation at the International Association of Agricultural Economists Conference, Gold Coast, Australia, August, 12-18, 2006.

Martinez SR 2002 Vertical coordination of marketing systems: lessons from the poultry, egg and pork industry. United State Department for Agriculture, Agricultural Economics Report 807, USDA, Washington, DC, USA.

McPherson MA 1992 Growth and survival of small Southern African firms (Unpublished PhD thesis), East Lansing: Michigan State University, USA.

Ministry of Food and Agriculture [MoFA] 2020 Revamping the poultry sector. Accessed at http://mofa.gov.gh/site/media-centre/agricultural-articles/321-revamping-the-poultrysector-in-ghana\# on July 2020. 
Misund B 2016. Vertical integration and value-relevance: empirical evidence from oil and gas

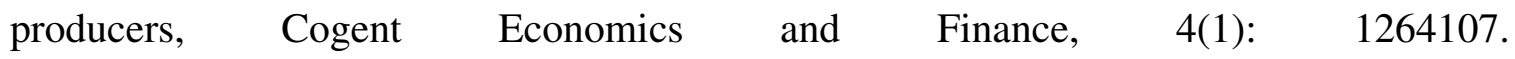
https://doi.org/10.1080/23322039.2016.1264107

Nimoh F, Tham-Agyekum EK, Awuku SM 2012 Factors influencing access of poultry farmers to credit: The Case of the Agricultural Development Bank (ADB) in Ga East Municipality, Ghana. Management 3(1): 54-58 doi: 10.5923/j.mm.20130301.11

Perry MK 1989. Vertical integration: determinants and effects. In R Schmalensee, R Willig (eds) Handbook of Industrial Organization, Amsterdam: North Holland

Presser HB Baldwin W 1980. Childcare as a constraint on employment: prevalence, correlates, and bearings on the work and fertility nexus. Journal of Sociology 85:1202-1213.

Rehber E 1998 Vertical Integration in Agriculture and Contract Farming: Private Strategies, Public Strategies \& Food System Performance, Journal of Scientific Research, 2(1): 14-20, 2007

Robinson P, Sexton B, Edwin A 1994 The effect of education and experience on self-employment success, Journal of Business Venturing, 9(2):141-156.

Stigler G 1951 The division of labor is limited by the extent of the market. Journal of Political Economy, 30(2): 185-193.

Tucker I, Wilder RP 1977 Trends in vertical integration in the U.S. manufacturing sector. Journal of Industrial Economics, 26(1):81-94.

United States Department of Agriculture [USDA] (2017) Ghana poultry project (GPP); September 2015 - October, 2020. Access at www.acdivoca.org.

University of California Los Angeles (UCLA) 2020. Introduction to SAS: Statistical Consulting Group. Zero-Inflated Poisson Regression | Stata Annotated Output (ucla.edu), accessed on 23rd December, 2020 
Vesey JT 1978 Vertical integration: its effect on business performance. Managerial Planning, 26(6): 11-15.

Ward CE 1997 Vertical integration comparison: beef, pork and poultry. Selected paper submitted to the Western Agricultural Economics Association, February, 1997.

Winkelmann R, Zimmermann KF 1998. Is job stability declining in Germany? Evidence from count data models. Applied Economics, 30(11), 1413 - 1420.

Winkelmann R, Zimmermann KF 1995 Recent development in count data modelling: Theory and application. Journal of Economic Surveys, 9(1): 1-24.

Young AA 1928. Increasing returns and economic progress. Economic Journal, 38: 523-542.

Yusuf OB Afolabi RF, Agbaje AS 2018 Modelling Excess Zeros in Count Data with Application to Antenatal Care Utilization, International Journal of Statistics and Probability; 7(3): doi:10.5539/ijsp.v7n3p22 
Figures

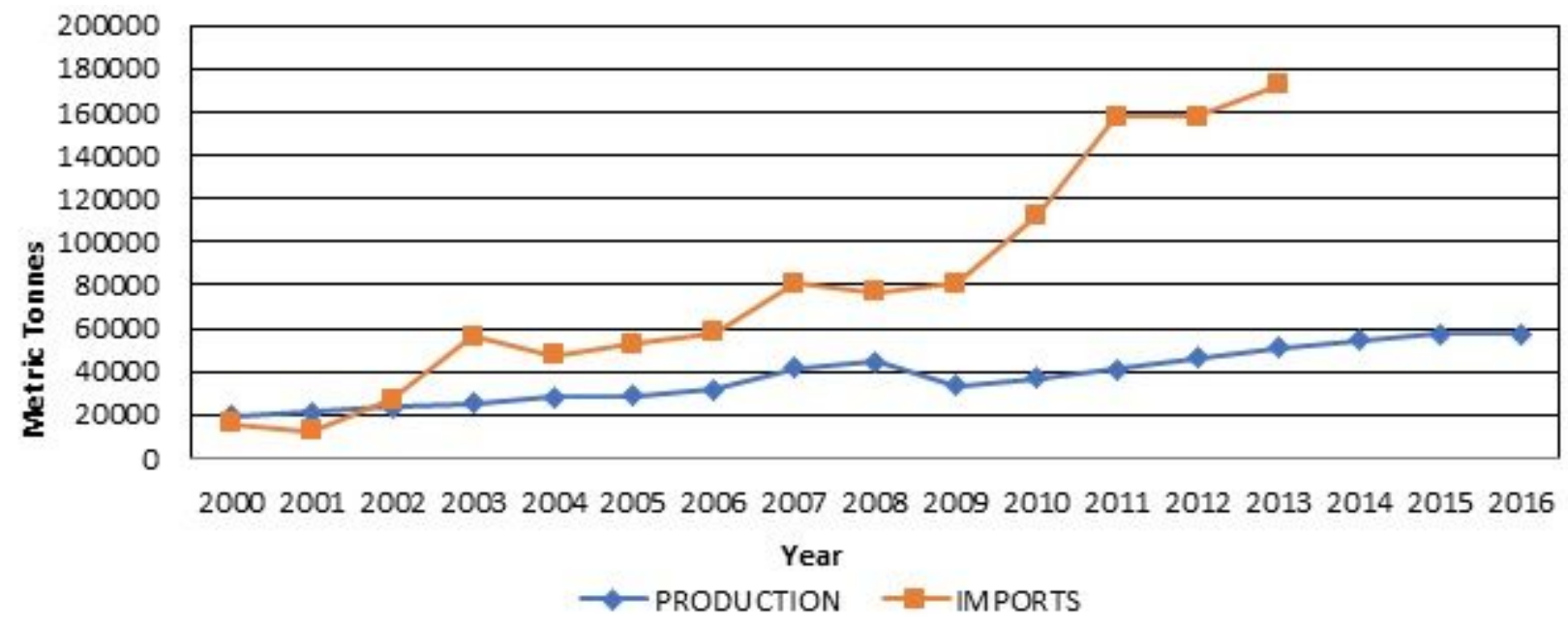

Figure 1

Production and Importation of Poultry in Ghana, 2000-2016 Data source: FAOSTAT Database, Various Years

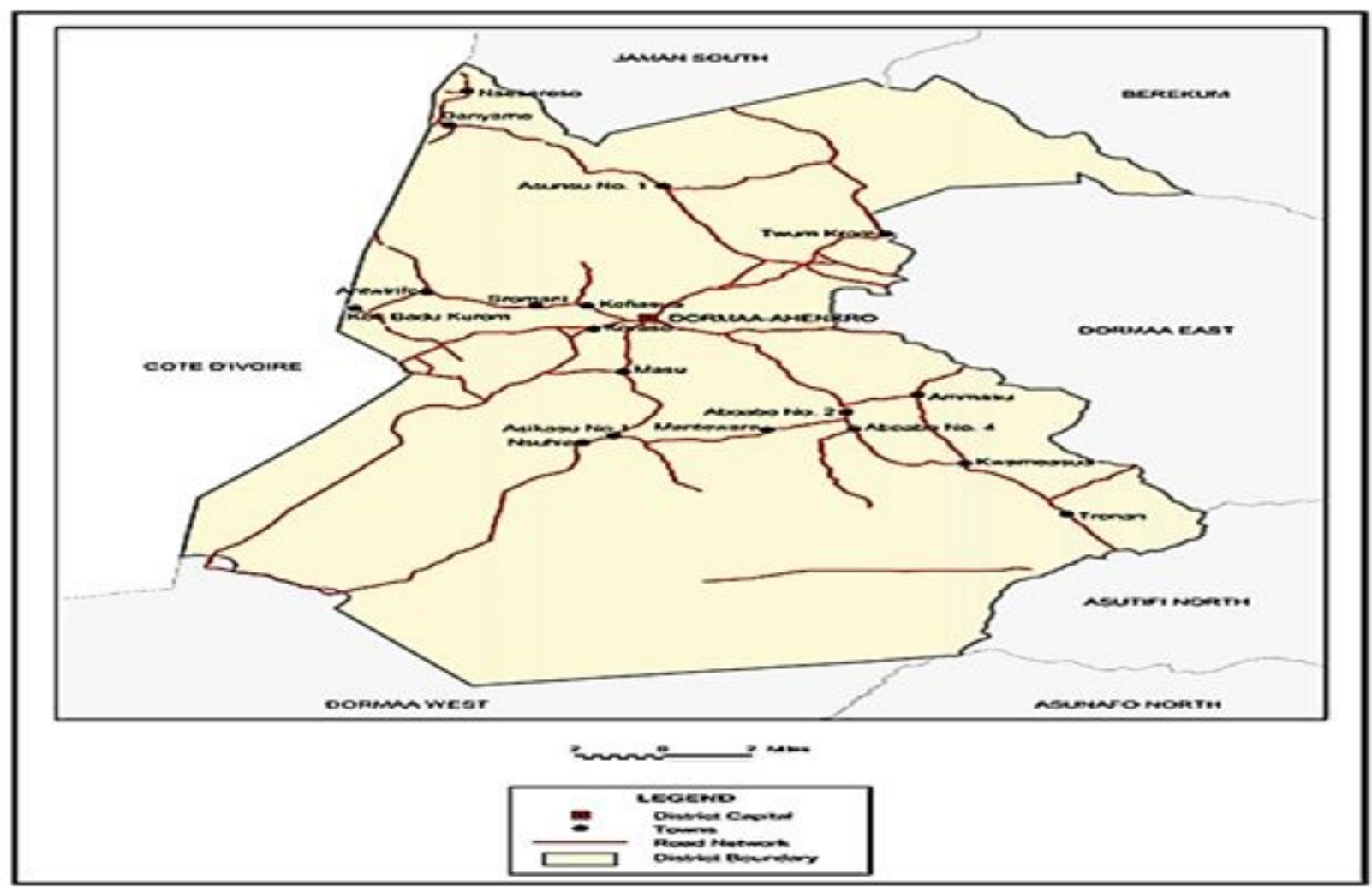

Figure 2

Map of Dormaa Municipality (Ghana Statistical Service, [GSS] 2010) 


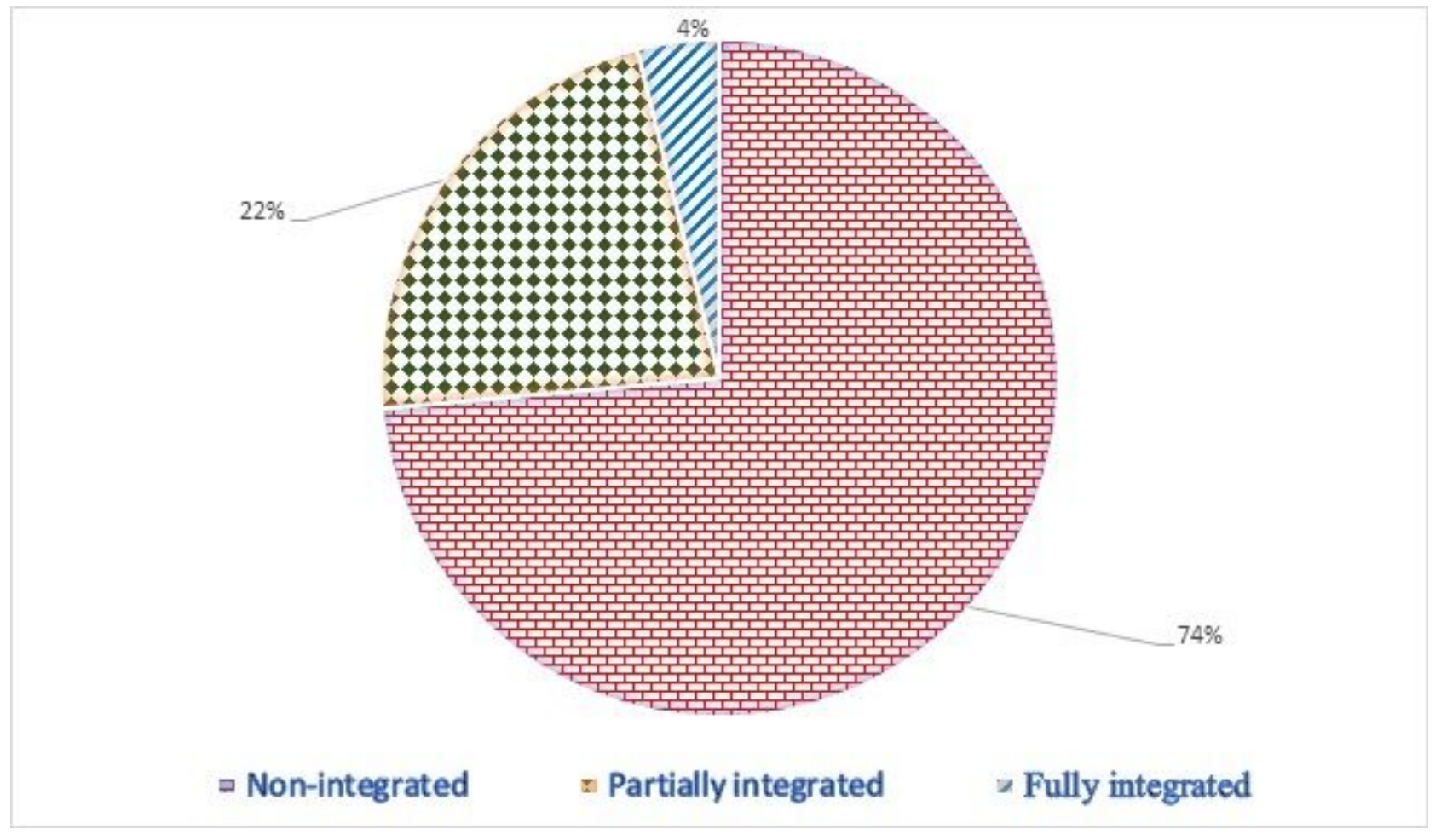

Figure 3

Levels of vertical integration among poultry farms 